Original Research Article

\title{
Role of betahistine in glycemic control of obese subjects: a placebo- controlled clinical trial
}

\author{
Hayder H. Al-Anbari ${ }^{1}$, Ahmed S. Sahib ${ }^{2}$, Amer O. Al-Mukhtar ${ }^{3}$
}

\begin{abstract}
${ }^{1}$ Department of Pharmacy, AlSafwa University College,

Karbalaa-Iraq

${ }^{2}$ Department of Pharmacology,

University of Karbalaa, College

of Pharmacy, Karbalaa-Iraq

${ }^{3}$ Department of Medicine,

University of Karbalaa, College

of Medicine, Karbalaa-Iraq
\end{abstract}

Received: 03 November 2016

Accepted: 09 December 2016

\section{*Correspondence to:}

Dr. Ahmed S. Sahib,

Email:

ahmedsalih73@yahoo.com

Copyright: () the author(s), publisher and licensee Medip Academy. This is an openaccess article distributed under the terms of the Creative Commons Attribution NonCommercial License, which permits unrestricted noncommercial use, distribution, and reproduction in any medium, provided the original work is properly cited.

\begin{abstract}
Background: Poor glycemic control, insulin resistance and abnormal beta cell function are of the most important complications that associated with obesity, targeting of such complications with pharmacological agents depending on the already existing central mechanism may decrease the incidence of morbidity and mortality among obese subjects. Betahistine is an anti-vertigo drug, commonly prescribed to patients with balance disorders or to improve vertigo symptoms associated with Meniere's disease. The aim of this study was to investigate the effect of betahistine on glycemic status, insulin resistance and pancreatic function in obese subjects.

Methods: A randomized, placebo controlled trial was carried out on 72 obese subjecta of both sexes with age range of 18-50 years who allocated into two groups: Group A: 48 patients treated with $144 \mathrm{mg} /$ day in three divided every eight hours for twelve weeks. Group B: 24 patients treated with placebo for twelve weeks to serve as control. For each group, demographic data, liver and renal function tests beside the studied parameters were investigated at baseline and after 12 weeks.

Results: Administration of betahistine to obese subjects resulted in improvement in fasting blood glucose, glycosylated hemoglobin, insulin resistance and beta cell percent values after twelve weeks compared to baseline values and placebo treated group.

Conclusions: Administration of betahistine in a dose of $144 \mathrm{mg} /$ day for twelve weeks to obese subjects effectively improve glycemic control, insulin resistance and beta cell functions in these subjects, indicating the beneficial effect of betahistine in slowing or reversing the long term progress of obesity complications without incidence of any serious adverse effects, indicating its efficacy and safety.
\end{abstract}

Keywords: Betahistine, Glycemic control, Insulin resistance, Lifestyle change, Obesity

\section{INTRODUCTION}

Obesity was defined as a condition of abnormal or excess fat accumulation in adipose tissue, to the extent that impaired health. Body Mass Index (BMI) which is calculated as [(weight in $\mathrm{kg}$ ) / (height in $\left.\mathrm{m})^{2}\right]$, is the most useful population level measure of obesity, and it is a simple index to classify underweight, overweight and obesity in adults. The WHO has classified overweight and obesity in adults based on various BMI cutoffs. ${ }^{1}$

Obesity has become a major worldwide health problem. The incidence of obesity is rising continuously leading to morbidity, mortality and both medical and economical costs are expected to increase as well. ${ }^{2}$ In the last two decades, the world has seen a sustained increment in obesity, and the levels of overweight and obese people worldwide have reached epidemic proportions. ${ }^{3}$ Worldwide data demonstrate that $35 \%$ of females and $34 \%$ of males had overweight, whereas the prevalence of obesity was $14 \%$ in females, $10 \%$ in males and $12 \%$ in both genders. ${ }^{4}$ In the Eastern Mediterranean Region, the prevalence of overweight and obesity among both children and adults increased markedly through the past three decades. ${ }^{5}$ The prevalence of obesity reported by the WHO for the Iraqi population in 2005 was $8.3 \%$ and $19.1 \%$ for males and females respectively. ${ }^{6}$ In 2008 , 
another study concluded that obesity affects about $30 \%$ of adult population, with higher prevalence in women. ${ }^{7}$

In the last few years, and because of the economic improvement, Iraq has been developing a nutritional transition in eating habits and food consumption. Eventually, the dietary habits of young adults have been affected; so, overweight and obesity are expected to increasingly been observed among the young. Three years ago, another study was conducted to determine the prevalence of overweight and obesity and their associated risk factors among Karbala University students, found that prevalence of overweight and that of obesity were $22.9 \%$ and $5.6 \%$ respectively. $^{8}$

Obesity threatens to become the primary cause of noncommunicable diseases over the world, with high health and social costs. ${ }^{9,10}$

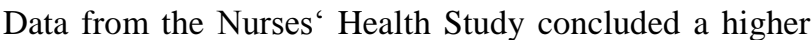
risk for DM in obese females. ${ }^{11}$ Similarly, a higher risk for diabetes was found for males with a BMI of $\geq 35$ $\mathrm{kg} / \mathrm{m}^{2}$ in the Health Professionals Follow-up Study. ${ }^{12}$ Another study found that the prevalence of diabetes raises with higher weight classes. Nearly a quarter of people with DM have poor glycemic control, and about half of adult diabetics were obese suggesting that weight reduction is an essential intervention in an effort to minimize the impact of diabetes on the health care system. $^{13}$

There are triple treatment objectives for obesity; short term that aimed to decrease weight; medium term aimed to reduce the associated cardiovascular risk factors; and long term for stopping the cardiovascular events and the obesity related morbidities. ${ }^{14}$

Concerning weight reduction, several studies that focused on obesity therapies (along with diet restriction and increasing physical activity), have proved that a moderate reduction of initial BMI could significantly improve blood pressure, serum lipid concentrations, increase insulin sensitivity or improve glycaemia, compared to diet restriction and increasing physical activity alone. ${ }^{15-17}$ It has been concluded that a body weight reduction of $7 \%$ improves cardiovascular risk factors and glycemic control in subjects with type 2 diabetes. ${ }^{18}$

Brain histamine plays an essential role in eating behaviour as it reduces appetite and has been considered a satiety signal, released during food intake. ${ }^{19}$ It modulates both sides of energy balance: decreasing intake and increasing expenditure. ${ }^{20}$ However, relatively few clinical studies were carried out to clarify a relationship between weight regulation and histamine modulators. ${ }^{21}$ Activation of $\mathrm{H} 1$ receptors in the preoptic area and paraventricular nucleus increases energy expenditure. Neuronal histamine and H1-Rs contribute also to the central regulation of energy homeostasis through sympathetic influences on uncoupling protein expression in brown adipose tissue. ${ }^{22}$ Histamine H1Receptor signaling is central to the regulation of the feeding rhythm, leptin sensitivity, and obesity. In normal conditions; histamine regulates food intake via acting on H1 receptors. ${ }^{23}$ These observations increase the possibility that histamine H1-R agonists might be an effective and novel means of therapy for the treatment of obesity and related metabolic disorders. ${ }^{24}$ Pre-synaptic $\mathrm{H} 3$ auto receptors regulate the release of histamine. The use of an $\mathrm{H} 3$ receptor antagonist (increased histamine release) induces hypophagia, which could be attenuated by $\mathrm{H} 1$ receptor antagonist. ${ }^{25}$ Accordingly, $\mathrm{H} 3$ antagonists may represent unique therapeutic target for the treatment of disorders of energy homeostasis. ${ }^{26}$ Recently, manyhuman studies are starting to provide evidence that the pharmacological manipulation of the histaminergic system influences weight gain and body mass index. ${ }^{27}$

Betahistine is an anti-vertigo drug, commonly prescribed to patients with balance disorders or to improve vertigo symptoms associated with Meniere's disease. Betahistine has two modes of action. Primarily, it has a direct agonistic effect on $\mathrm{H}_{1}$ receptors located within blood vessels of the inner ear. More importantly, the drug has powerful antagonistic effects at $\mathrm{H}_{3}$ receptors, thus increasing the levels of neurotransmitters serotonin, acetylcholine, norepinephrine, and histamine released from the nerve endings. ${ }^{28}$

Central nervous system histaminergic tone is thought to have a role in appetite regulation. $\mathrm{H}_{1}$ receptor agonists and $\mathrm{H}_{3}$ receptor antagonists reduce food intake. ${ }^{19}$ In animals, the central administration of histamine can decrease body weight and obesity by affecting both food intake and energy expenditure. ${ }^{22}$ Betahistine is a good candidate that fulfills the above mentioned mechanism and represents an interested and promised agent that may be used for such purposes.

The aim of this study is to investigate the effect of betahistine on the glycemic status, insulin sensitivity and pancreatic function in obese patients.

\section{METHODS}

This is a randomized, single-blind, prospective, placebo controlled trial. The study was carried out at the consultant clinic- AlHussain Teaching HospitalKarbalaa-Iraq, during the period between February till October 2015. The present study was approved by the institutional medical ethical committee.

\section{Patients' selection}

Seventy two obese patients of both sexes (36 for each), aged 18-50 years old, had been enrolled in this study, and were divided into two groups:

1. Group A: 48 patients (36 male/ 12 female) treated with Betahistine (Betaserc/ Solvay; Switzerland) 
$144 \mathrm{mg} /$ day in three divided every eight hours for twelve weeks.

2. Group B: 24 patients (12 male/12 female) treated with Glucose (SDI/Iraq) $500 \mathrm{mg} /$ day in two divided doses, every 12 hours for twelve weeks to serve as control.

Complete history was taken from each patient regarding age, marital state, past medical history, and previous treatment. A written consent from each patient to be involved in the study was obtained.

\section{Inclusion criteria}

Inclusion criteria include obese patients with BMI equals or more than $30 \mathrm{~kg} / \mathrm{m}^{2}$ whose age range between $18-50$ years.

\section{Exclusion criteria}

1. Patients with chronic kidney disease (CKD): Renal professionals consider the glomerular filtration rate (GFR) to be the best overall index of kidney function, with GFR less than 60 represents CKD. The National Kidney Foundation offers an easy to use on-line GFR calculator, and recommends using the CKD-EPI Creatinine Equation (2009) to estimate GFR.

2. Hepatic impairment: Aspartate aminotransferase (AST) or alanine aminotransferase (ALT) higher than two-folds the reference range.

3. Heart diseases (unstable angina, myocardial infarction, transient ischemic attacks/stroke, clinically significant arrhythmia, congestive heart failure (increased risk of lactic acidosis), or cardiac valve abnormalities.

4. Patients with a history of seasonal allergy, asthma, or peptic ulcer.

5. Known allergy to betahistine.

6. Pregnant or lactating women.

7. Known cases of type 1 or type 2 diabetes mellitus.

8. Patients taking antipsychotics, antidepressants, steroids, contraceptive pills, diuretics, laxatives, or antihistamines.

9. Patients with known history of thyroid dysfunction, Cushing's syndrome or Addison's disease.

10. Patients with medical history of physical characteristics (e.g. polydactyly) suggestive of genetic obesity (e.g., Prader-Willi syndrome, Bardet-Biedl syndrome).

11. Patients recently started a smoking cessation program.

12. Patients who are already on treatment with an antiobesity medication.

\section{Course of therapy}

The duration required for each individual patient to complete the course of the treatment was 12 weeks, clinical assessment was carried out at baseline and every
4 weeks till the end of this period. Laboratory investigations were evaluated at baseline and by the end of the study.

\section{Diet program}

The patients were instructed to follow the diet regimen adapted by the specialist who provides a low-calorie diet (LCD) of 1000-1200 kcal/day as the National Heart, Lung, and Blood Institute (NHLBI) Obesity Education Initiative recommended 1,200 to $1,600 \mathrm{kcal} /$ day for men, and 1,000 to $1,200 \mathrm{kcal} /$ day for women as a Low calorie $\operatorname{diet}(\mathrm{LCD}){ }^{29}$

\section{Physical activity}

The patients were instructed to practice a medium intensity exercise for 60-90 minutes/day. The Dietary Guidelines for Americans recommend that to lose weight, obese people have to participate at least 60 to 90 minutes of moderate- to vigorous-intensity daily physical activity, along with caloric intake restrictions. ${ }^{30}$

\section{Study design}

Before starting therapy, all the patients groups were investigated for baseline weight, height, body mass index (BMI), serum levels of liver transaminases ALT+AST), urea and creatinine, to exclude any hepatic or renal function abnormality. Glycosylated hemoglobin (HbA1c), fasting blood sugar (FBS), C- peptide, insulin resistance, and pancreatic beta-cell function percent.

All the patients were told to come to clinic for follow up every four weeks, to document any variation in their baseline data. Another target of this four-weekly visit is to keep monitoring their diet regimen and the instructed daily exercise, and whether any adverse drug reaction or any health abnormality has taken place.

After completing therapy course, all the patients were examined again for their weight, height, body mass index (BMI), HbA1c, FBS, C- peptide, insulin resistance and pancreatic betacell function to check the changes by the end of the course.

\section{Anthropometric parameters assessment}

Body weight, height measurements: an electronic balance was used for body weight measurements, which was already provided with a scaled board for measuring height. The body mass index was calculated using the equation:

Body mass index = weight in kilograms/ height in square meters. ${ }^{1}$ 


\section{Blood collection and serum separation}

A blood sample of ten milliliters was collected from each patient by vein puncture, the blood samples were collected from the patients by using a plastic $10 \mathrm{ml}$ syringe, and EDTA (Ethylene-diamine-tetra acetic acid) tube. For $\mathrm{HbAlc}$ analysis, $2.5 \mathrm{ml}$ were immediately isolated, and the rest $7.5 \mathrm{ml}$ were left to stand for 15 minutes in a gel containing tube (the gel enhances faster separation), then centrifugation would be done for 15-20 minutes at a rate of 4000 rounds per minute. An automatic pipette was utilized to move the sera from the test tubes to the Eppendroff's tubes (dividing each serum sample into six parts, each has a volume of about $0.5 \mathrm{ml}$ ) were the samples would be kept and frozen. ${ }^{31}$

Using HOMA2- Index, and by the aid of the measured cpeptide and fasting glucose values, insulin resistance and the percent of functioning pancreatic Beta-cells were calculated. $^{32}$

\section{Biochemical parameters assessment}

1. Fasting blood sugar (FBS): Glucose is oxidized by glucose oxidase to gluconic acid and hydrogen peroxide, reacts with chloro-4-phenol to form a red quinone-imine. The absorbance of the colored complex, proportional to the concentration of glucose in the sample is measured at $500 \mathrm{~nm}^{33}$

2. Glycosylated hemoglobin $A 1_{C}$ percentage ( $\mathrm{HbAlc}$ ) $\%$ : the reagent kit bases on antigen-antibody reaction to directly test the percentage of $\mathrm{HbAlc}$ from the total hemoglobin. ${ }^{34}$

3. Serum liver transaminases (AST, $A L T)$ : these were measured prior to recruitment, in order to exclude hepatic impairment. Liver transaminases (AST and ALT) are useful biomarkers of liver injury in a patient with some degree of intact liver function. ${ }^{35}$

4. Serum creatinine: Measuring serum creatinine is a simple test, and it is the most commonly used indicator of renal function. The creatinine contained in the sample is hydrolyzed to N-methyl-hydantoin with release of ammonia. Later on, hydrogen peroxide is formed which reacts with an indicator to form a blue dye which is proportional to the creatinine concentration in the sample. At $37^{\circ} \mathrm{C}$ the dye formed is measured at a $642 \mathrm{~nm}$ and the creatinine concentration detected after about 2 minutes in $\mathrm{mg} / \mathrm{dl}$ or $\mathrm{mmol} / \mathrm{l}^{36}$

5. Estimated Glomerular Filteration Ratio (eGFR): Using the online eGFR calculator, approved by the National Kidney Foundation (NKF), eGFR was calculated from the values of serum creatinine, age and gender. ${ }^{37}$

6. Serum C-peptide: Principle of test: The c-peptide present in the test sample is bound with antibody immobilized on a magnetic solid phase and enzymelabeled monoclonal antibody in the test cups. The amount of enzyme-labeled monoclonal antibody that binds to the beads is directly proportional to the
C-peptide concentration in the test sample. A standard curve is constructed, and unknown sample concentrations are calculated using the curve. Normal range: 0.5 to 2.0 nanograms per milliliter $(\mathrm{ng} / \mathrm{mL}) .^{38}$

7. Estimation of insulin resistance (IR) and functioning $\beta$-cell percentage: HOMA 2 Index Calculator was used, available online. They published computer software so that insulin resistance and $\beta$-cell function can be estimated from fasting glucose and insulin or C-peptide levels. C-peptide, a measure of insulin secretion (not insulin action), was used in HOMA modelling of both $\beta$-cell function and IR. HOMA2 is distinctly better than HOMA1 in predicting indexes of beta -cell function and insulin resistance. $^{39}$

\section{Adverse effect}

Adverse effects that might appear due to the use of the medications were monitored for each patient. They were instructed to stop taking therapy and seek consultation when they feel anything wrong or abnormal immediately.

\section{Statistical analysis}

The data were subjected to statistical analysis using the student t-test for comparison of means between studied groups, utilizing SPSS 18 version. All the data were expressed as mean \pm standard deviation of the mean. PValue $\leq 0.01$ were considered highly significant.

\section{RESULTS}

Table 1: Characteristics of the enrolled patients.

\begin{tabular}{|llll|}
\hline Variable & $\begin{array}{l}\text { Group A } \\
(\mathbf{n = 4 8})\end{array}$ & $\begin{array}{l}\text { Group B } \\
(\mathbf{n = 2 4})\end{array}$ & $\begin{array}{l}\text { P- } \\
\text { value }\end{array}$ \\
\hline Age $($ year $)$ & $35.19 \pm 11.02$ & $36.71 \pm 8.81$ & 0.529 \\
\hline BMI $\left(\mathrm{kg} / \mathrm{m}^{2}\right)$ & $37.94 \pm 3.80$ & $37.78 \pm 2.98$ & 0.846 \\
\hline $\begin{array}{l}\text { Serum Creatinine } \\
(\mathrm{mg} / \mathrm{dL})\end{array}$ & $0.79 \pm 0.07$ & $0.78 \pm 0.08$ & 0.571 \\
\hline $\begin{array}{l}\text { Blood urea } \\
(\mathrm{mg} / \mathrm{dL})\end{array}$ & $25.14 \pm 5.59$ & $25.33 \pm 5.80$ & 0.896 \\
\hline $\begin{array}{l}\text { eGFR } \\
(\mathrm{ml} / \mathrm{min} / 1.73 \mathrm{~m} 2)\end{array}$ & $85 \pm 12.29$ & $84.71 \pm 8.48$ & 0.907 \\
\hline $\begin{array}{l}\text { Serum AST } \\
\text { (I.U/L) }\end{array}$ & $23.08 \pm 7.71$ & $21.83 \pm 5.44$ & 0.43 \\
\hline $\begin{array}{l}\text { Serum ALT } \\
\text { (I.U/L) }\end{array}$ & $22.52 \pm 6.91$ & $22.17 \pm 4.98$ & 0.805 \\
\hline
\end{tabular}

Results represent mean $\pm \mathrm{SD}$; group $\mathrm{A}=$ betahistine; group $\mathrm{B}=$ placebo; $\mathrm{BMI}=$ body mass index; $\mathrm{e}-\mathrm{GFR}=$ estimated glomerular filtration rate; AST= Aspartate aminotransferase; $\mathrm{ALT}=$ Serum alanine aminotransferase .

Table 1 showed the baseline data of the enrolled obese patients, there is no statistically significant difference between groups concerning participant's age, and body mass index. Liver transaminases results showed normal liver function; estimated glomerular filtration rate (e- 
GFR), blood urea level and serum creatinine level showed normal kidney function with no statistically significant difference between obese patients in this regard.

Concerning glycemic status and beta cell function of pancreas in obese patients, Table 2 showed that there is no significant difference between the betahistine and placebo treated groups of glycemic control baseline values represented by fasting blood glucose and glycosylated hemoglobin levels, also in case of pancrease function as represented by measurements of c-peptide levels, insulin resistance and beta cell function.

Table 2: Baseline data of glycemic status and pancreatic function of betahistine group versus placebo.

\begin{tabular}{|llll|}
\hline \hline Variable & $\begin{array}{l}\text { Group A } \\
(\mathbf{n = 4 8 )}\end{array}$ & $\begin{array}{l}\text { Group B } \\
(\mathbf{n = 2 4 )}\end{array}$ & $\begin{array}{l}\text { P- } \\
\text { value }\end{array}$ \\
\hline FBS (mg/dL) & $97.33 \pm 3.28$ & $97.20 \pm 4.08$ & 0.897 \\
\hline HbA1c (\%) & $5.72 \pm 0.39$ & $5.67 \pm 0.37$ & 0.637 \\
\hline $\begin{array}{l}\text { C-peptide } \\
\text { (ng/ml) }\end{array}$ & $3.67 \pm 0.42$ & $3.72 \pm 0.52$ & 0.69 \\
\hline $\begin{array}{l}\text { Insulin } \\
\text { resistance } \\
\text { (unit) }\end{array}$ & $2.75 \pm 0.33$ & $2.80 \pm 0.42$ & 0.646 \\
\hline $\begin{array}{l}\text { B- Cell \% } \\
\text { (unit) }\end{array}$ & $163.04 \pm 13.67$ & $166.31 \pm 12.14$ & 0.306 \\
\hline
\end{tabular}

Results represent mean $\pm \mathrm{SD}$; group $\mathrm{A}=$ betahistine; group $\mathrm{B}=$ placebo; FBS = fasting blood sugar; $\mathrm{HbA1c}=$ glycosylated hemoglobin.

After 12 weeks of intervention, Table 3 showed that administration of betahistine resulted in highly significant differences in glycemic status and beta cell function of pancreas in obese patients compared to placebo group.

Table 3: Effect of betahistine administration for 12 weeks on glycemic status and pancreatic function of obese patients versus placebo.

\begin{tabular}{|llll|}
\hline Variable & $\begin{array}{l}\text { Group A } \\
(\mathbf{n = 4 8 )}\end{array}$ & $\begin{array}{l}\text { Group B } \\
(\mathbf{n = 2 4})\end{array}$ & $\begin{array}{l}\text { P- } \\
\text { value }\end{array}$ \\
\hline FBS (mg/dL) & $93.81 \pm 3.05$ & $96.58 \pm 3.99$ & 0.005 \\
\hline HbA1c (\%) & $4.69 \pm 0.33$ & $5.65 \pm 0.38$ & 0.0 \\
\hline $\begin{array}{l}\text { C-peptide } \\
\text { (ng/ml) }\end{array}$ & $2.63 \pm 0.31$ & $3.62 \pm 0.58$ & 0.0 \\
\hline $\begin{array}{l}\text { Insulin } \\
\text { resistance (unit) }\end{array}$ & $1.95 \pm 0.24$ & $2.72 \pm 0.46$ & 0.0 \\
\hline B- Cell \% (unit) & $138.44 \pm 10.22$ & $164.59 \pm 14.53$ & 0.0 \\
\hline
\end{tabular}

Results represent mean $\pm \mathrm{SD}$; group $\mathrm{A}=$ betahistine; group $\mathrm{B}=$ placebo; $\mathrm{FBS}=$ fasting blood sugar; $\mathrm{HbA1}=$ glycosylated hemoglobin

Furthermore, the fasting blood glucose and glycosylated hemoglobin levels were decreased after betahistine administration highly significantly by $3.61 \%$ and $18 \%$ respectively compared to pre-treatment values, Figure 1A and 1-B.

Concerning beta cell function of pancreas in obese patients, administration of betahistine for 12 weeks to obese patients resulted in highly significantly reduction of studied parameters compared to pre-treatment values; the reduction percent was $28.33 \%$ in c-peptide level, $29 \%$ in the value of insulin resistance and $15 \%$ in B-cell\%, Figure 1-C, 1-D and 1-E respectively.
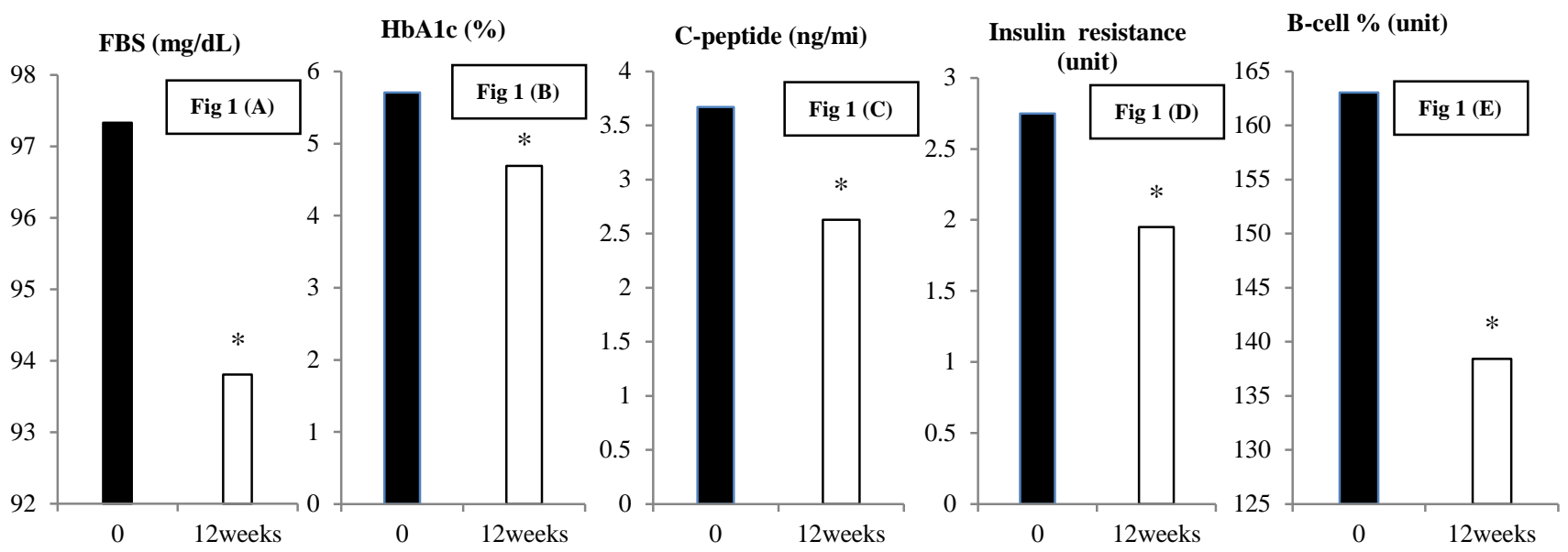

Figure 1: Comparison between pre-and post- betahistine administration for 12 weeks on glycemic status and pancreatic function of obese patients. A: Fasting blood glucose; B: Glucosylated hemoglobin; C: c-peptide serum level; D: Insulin resistance; E: Beta cell function; *: Highly significant change $\mathbf{p} \leq \mathbf{0 . 0 1}$.

\section{Adverse events associated with treatment groups}

In the current study, results exhibited low incidence of adverse events in all participants in the different treatment groups. No serious adverse effects were noticed throughout the study course, and none of the patients withdrew because of the adverse effects. Only one patient receiving betahistine had reported headache for the first 
two days. One case of dizziness had been reported by a patient from the control group.

\section{DISCUSSION}

The influence of lifestyle intervention programs on body mass index and all the long term associated complications including glycemic control and insulin resistance are questionable, taking in consideration the high drop-out and the recurrent relapse of obesity in many patients. Therefore, in clinical practice, the continuous trial on using new pharmacological agent to the conventional management is often considered. ${ }^{40}$ Accordingly, this placebo-controlled study had been carried out to test the short term effects of potentially new weight loss medication betahistine along with low calorie diet and medium intensity exercise (MIE), on weight and its consequences on anthropometric parameters, glycemic control, pancreatic function taking in consideration the tolerability of the medication and the severity of probable adverse effects.

Many studies have found that histamine $\mathrm{H}_{1}$ receptor blockade plays a principal role in drug induced weight gain, therefore, $\mathrm{H}_{1}$ receptor blockade represents an important novel therapeutic target for controlling weight gain. ${ }^{41}$ This finding was confirmed by recent clinical finding in patients with schizophrenia, a combination therapy of olanzapine, betahistine and reboxetine had significantly less weight gain compare to patients on olanzapine only. ${ }^{42}$ Another study showed that betahistine co-treatment could be an effective combination therapy to decrease olanzapine-induced weight gain side effects without influencing olanzapine's actions on $5-\mathrm{HT}_{2}$ receptor transmissions. ${ }^{43}$ In 2008 , a study reported a significant weight reduction in women aged less than 50 years who received $48 \mathrm{mg}$ betahistine/day rather than a placebo throughout a 12-week randomized controlled trial. ${ }^{44}$ In 2012; a review regarded betahistine as one of the drug candidates for future role as a centrally acting anti-obesity medications. ${ }^{45}$

In this study, administration of betahistine (along with low calorie diet and medium intensity exercise) caused a significant reduction in FPG, $\mathrm{HbA} 1 \mathrm{c} \%$, Cpeptide, IR and functioning Beta Cell percent. Betahistine treatment achieved a highly statistically significant difference compared to the placebo group. Recent data showed that the highly significant weight reduction caused by betahistine (not shown) compared to plaebo might be associated with this highly significant lowering in fasting plasma glucose and glycosylated hemoglobin. This result is consistent with several clinical trials concerning obesity, that weight losses were significantly correlated with decreasing FPG and $\mathrm{HbA} 1 \mathrm{c} \%{ }^{46} \mathrm{C}$-peptide and insulin are released in equal amounts in the blood, and are produced at the same rate, yet, they are processed and eliminated in different ways, and both are makers for $\beta$ cell function. ${ }^{47}$ After insulin release from the pancreas, it undergoes substantial first-pass clearance by the liver.
Being so, measuring peripheral levels of insulin is an unreliable indicator of pancreatic insulin secretion, besides, either proinsulin or insulin antibodies may interfere with insulin assays. C-peptide is a more reliable estimator of insulin secretion as it is not cleared by the liver, owing a longer half-life than insulin (30 minutes versus 4 minutes for insulin), and its pharmacokinetics have been well studied in researches [48]. In nondiabetic subjects, obesity is accompanied by a modest increase in $\beta$ - cell mass, estimated by $10-30 \%$ for each $10 \mathrm{~kg}$ of weight excess (represented by more than $100 \% \beta$-cell function). ${ }^{49}$ BMI increase exerts a positive influence on fasting insulin secretion, apart from that of insulin resistance, so, obesity may represent a primary insulin hypersecretory condition. Therefore; weight loss is associated with prominent decrease in insulin resistance and insulin over normal secretion.$^{50}$ The present study results yield a highly significant reduction in C-peptide, which could reflect a reduced insulin over-secretion, since they are produced by the pancreas in the same amount, insulin resistance and $\beta$ - cell function percent. These results are consistent with other studies, in a placebo controlled clinical study $\beta$-cell function and insulin resistance were improved after 12 week treatment with metformin due to improvement in insulin action.$^{51}$ The present study results are also consistent with that of another study in 2008, which showed that weight loss concurrently improves $\beta$-cell function, and improves insulin action in obese adults, and these metabolic actions probably reduce the risk of developing T2D.$^{52}$ There is a lack of clinical studies that evaluated betahistine in a dose of $96 \mathrm{mg}$ per day on glycemic control, pancreatic endocrine function. Betahistine acts as a histamine $\mathrm{H}_{1}$ receptor agonist, and a histamine $\mathrm{H}_{3}$ receptor antagonist. ${ }^{28}$ Histamine is synthesized from L-histidine by the enzyme histidine decarboxylase (HDC). HDC knockout (KO) mice were found to show clinical features of visceral obesity, hyperleptinemia, and reduced glucose tolerance ${ }^{53}$ A sustained increase in skeletal muscle blood flow follows an acute session of medium-intensity exercise, and this sustained vasodilatation is shown to be mediated by two ( $\mathrm{H} 1$ and $\mathrm{H} 2)$ histamine receptor subtypes. ${ }^{54} \mathrm{H} 1 \mathrm{R}$ signaling has been involved in central nervous system and pancreas to regulate glucose metabolism, whereas $\mathrm{H} 2 \mathrm{R}$ signaling has been primarily correlated to peripheral action in the liver and skeletal muscle through adiponectin system to control both lipid and glucose metabolisms. ${ }^{55}$

Taken together, Betahistine may contribute to glucose regulation that lead to good glycemic control through its peripheral histaminergic action in addition to appetite suppression.

In the current study, all the patients underwent lifestyle intervention (expressed by dieting and increased physical activity) in addition to betahistine (or placebo). No serious adverse effects were noticed throughout the study course, and none of the patients withdrew because of the adverse effects. Only one patient receiving betahistine 
experienced headache for the first two days. One case of dizziness for the first few days had been reported by a patient receiving placebo, which might be due to changing the lifestyle. The frequency of adverse event observed with betahistine did not differ from that seen in the control group. A study used betahistine for obese women in three different doses (48, 96 and 144mg/day) no participant reported a serious adverse event. The adverse events were alike between women in the betahistine and placebo groups. ${ }^{56}$ The dose of $144 \mathrm{mg} / \mathrm{d}$ was tried because this was the highest dose for which previous human safety data were published. ${ }^{57}$ In addition, other study was carried out to evaluate the clinical benefit and the side effects of betahistine in high doses ranging from $288 \mathrm{mg}$ - $480 \mathrm{mg}$ per day in patients with Menière's disease and the side effects were mild, self-limiting, and did not require any change in the treatment strategy. ${ }^{58}$

Overall, results exhibited low incidence of adverse events in all participants, and the adverse events were comparable between betahistine and placebo, indicating the safety of betahistine in the administered dose.

\section{CONCLUSION}

In conclusion, administration of betahistine in a dose of $144 \mathrm{mg} /$ day for twelve weeks to obese subjects effectively improve glycemic control, insulin resistance and beta cell functions in these subjects, indicating the beneficial effect of betahistine in slowing or reversing the long term progress of obesity complications without incidence of any serious adverse effects, indicating its efficacy and safety.

\section{Funding: No funding sources} Conflict of interest: None declared

Ethical approval: The study was approved by the Institutional Ethics Committee

\section{REFERENCES}

1. WHO definition for Obesity and overweight, facts sheet No 311, 2008, WHO definition for Obesity and overweight, facts sheet No 311, 2008, Updated January 2015.

2. Klop B, Elte JWF, Cabezas CM. Dyslipidemia in Obesity: Mechanisms and Potential Targets. Nutrients. 2013;5(4):1218-40.

3. Finucane MM, Stevens GA, Cowan MJ, Danaei G, Lin JK, Paciorek CJ, et al. National, regional, and global trends in body-mass index since 1980: systematic analysis of health examination surveys and epidemiological studies with 960 country-years and 9.1 million participants. Lancet. 2011;377:55767.

4. WHO Global Health Observatory (GHO). Overweight and obesity. [Updated: 04/Apr/2011; cited: 28/May/2013]. From: http://www.who.int/gho/ncd /risk factors /overweight/en/index.html.
5. Musaiger AO, Al-Hazzaa HM. Prevalence and risk factors associated with nutrition-related noncommunicable diseases in the Eastern Mediterranean region, International Journal of General Medicine. 2012:5:199-217.

6. WHO 2005. WHO Global Infobase Indicators. Available at: https:// apps.who.int/infobase/Indicators.aspx.

7. Al-Hilaly KA, Aboud HA, Al-Ghabban SI. Prevalence of Obesity among Adult Population in Karbala. Kufa Medical Journal. 2008;11(1):326-34.

8. Al-Ghabban SI. Prevalence of Overweight and Obesity among Students in University of Kerbala, Medical Journal of Babylon. 2013;10:205-18.

9. Grundy SM. Multifactorial causation of obesity: implications for prevention. Am $\mathrm{J}$ Clin Nutr. 1998;67:563S-72S.

10. Brownell KD, Frieden TR. Ounces of prevention-The public policy case for taxes on sugared beverages. $\mathrm{N}$ Engl J Med. 2009;360:1805-8.

11. Colditz GA, Willett WC, Rotnitzky A, Manson JE. Weight gain as a risk factor for clinical diabetes mellitus in women. Ann Intern Med. 1995;122:481-6.

12. Chan JM, Rimm EB, Colditz GA, Stampfer MJ, Willett WC. Obesity and fat distribution and weight gain as risk factors for clinical diabetes in men. Diabetes Care. 1994;17:961-9.

13. Nguyen NT, Nguyen XM, Lane J, Wang P. Relationship between obesity and diabetes in a US adult population: findings from the National Health and Nutrition Examination Survey, 1999-2006. Obes Surg. 2011;21(3):351-5.

14. Idelevich E, Kirch W, Schindler C. Current pharmacotherapeutic concepts for the treatment of obesity in adults. Ther Adv Cardiovasc Dis. 2009;3:75-90.

15. Kanders BS, Blackburn GL, Lavin P, Norton D. Weight loss outcome and health benefits associated with the Optifast program in the treatment of obesity. Int J Obes. 1989;13(2):131-4.

16. Black PH. The inflammatory consequences of psychologic stress: relationship to insulin resistance, obesity, atheroscle-rosis and diabetes mellitus, type II. Med Hypotheses. 2006;67:879-91.

17. Yanovski SZ, Bain RP, Williamson DF. Report of a National Institutes of Health-Centers for Disease Control and Prevention workshop on the feasibility of conducting a randomized clinical trial to estimate the long-term health effects of intentional weight loss in obese persons. Am J Clin Nutr. 1999;69:366-72.

18. Wing RR, Lang W, Wadden TA, Safford M, Knowler WC, Bertoni AG, et al. Look AHEAD Research Group. Benefits of modest weight loss in improving cardiovascular risk factors in overweight and obese individuals with type 2 diabetes. Diabetes Care. 2011;34(7):1481-6.

19. Sakata T, Yoshimatsu H, Kurokawa M. Hypothalamic neuronal histamine: implications of its homeostatic control of energy metabolism. Nutrition. 1997;13:403-11. 
20. Passani MB, Blandina P, Torrealba F. The histamine H3 receptor and eating behavior. J Pharmacol Exp Ther. 2011;336(1):24-9.

21. Deng C, Weston-Green K, Huang XF. The role of histaminergic $\mathrm{H} 1$ and $\mathrm{H} 3$ receptors in food intake: a mechanism for atypical antipsychoticinduced weight gain? Prog Neuropsychopharmacol Biol Psychiatry. 2010;34:1-4.

22. Masaki T, Yoshimatsu H, Chiba S, Watanabe T, Sakata T. Central infusion of histamine reduces fat accumulation and upregulates UCP family in leptinresistant obese mice. Diabetes. 2001;50:376-84.

23. Lett TAP, Wallace TJM, Chowdhury NI. Pharmacogenetics of antipsychotic-induced weight gain: review and clinical implications. Mol Psychiatry. 2012;17(3):242-66.

24. Masaki T, Chiba S, Yasuda T, Noguchi H, Kakuma $\mathrm{T}$, Watanabe $\mathrm{T}$, et al. Involvement of hypothalamic histamine $\mathrm{H} 1$ receptor in the regulation of feeding rhythm and obesity. Diabetes. 2004;53(9):2250-60.

25. Hancock AA, Brune ME. Assessment of pharmacology and potential anti-obesity properties of H3 receptor antagonists/inverse agonists. Expert Opin. Investig. Drugs. 2005;14:223-41.

26. Esbenshade TA, Fox GB, Cowart MD. Histamine H3 receptor antagonists, preclinical promise for treating obesity and cognitive disorders, Molecular Interventions. 2006;6:77-88.

27. Provensi G, Blandina P, Passani MB. The histaminergic system as a target for the prevention of obesity and metabolic syndrome. Neuropharmacology. 2016;106:3-12.

28. Botta L, Mira E, Valli S, Zucca G, Perin P, Benvenuti $\mathrm{C}$, et al. Effects of betahistine and of its metabolites on vestibular sensory organs. Acta Otorhinolaryngol Ital 2001;21(66):24-30.

29. NHLBI Obesity Education Initiative Expert Panel on the Identification, Evaluation, and Treatment of Obesity in Adults (US). Clinical Guidelines on the Identification, Evaluation, and Treatment of Overweight and Obesity in Adults: The Evidence Report. Bethesda (MD): National Heart, Lung, and Blood Institute; 1998 Sep.

30. Dietary Guidelines for Americans, Department of Agriculture (USDA) and the Department of Health and Human Services (HHS). 2010.

31. Henry JB. Clinical Diagnosis and Management by Laboratory Methods, Volume 1, W.B Saunders Company, Philadelphia; 1979:60.

32. Matthews DR, Hosker JP, Rudenski AS, Naylor BA, Treacher DF, Turner RC. Homeostasis model assessment: insulin resistance and beta-cell function from fasting plasma glucose and insulin concentrations in man. Diabetologia. 1985;28(7):4129.

33. Alan HH, Wu B. Tietz Clinical Guide to Laboratory Tests Fourth Edition. 2006.

34. Little RR. Glycated Hemoglobin StandardizationNational Glycohemoglobin Standardization Program
(NGSP) perspective, Clin. Chem. Lab. Med 2003;41:1191-8.

35. Deneke U, Rittersdorf W, Werner W. Performance data of Reflotron-GOT (AST) dry chemistry test for Reflotron. Clin. Chem. 1985;31:921.

36. Carstensen CA, Nagel R, Knoll E, Wisser H, Weidemann G, Riesen WF, et al. Development and evaluation of a reagent carrier with a new reaction sequence for the determination of creatinine in blood, plasma, serum and urine. Eur $\mathrm{J}$ Clin Chem Clin Biochem. 1993;31(5):335-46.

37. NKF-KDOQI Clinical Practice Guidelines for Anemia of Chronic Kidney Disease: Update 2000. Am J Kidney Disease. 2001;77:S182-288.

38. Beischer W. Proinsulin and C-Peptide in Humans. Hormones in Normal and Abnormal Human Tissues. Volume 3K, Fotherby and Pal, S., ed. (Berlin: Walter DeGruyter); 1983:1-43.

39. Caumo A, Perseghin G, Lattuada G, Ragogna F, Brunani A, Luzi L. Comparing the original (HOMA1) and the updated (HOMA2) method: evidence that HOMA2 is more reliable than HOMA1. Diabetes. 2007;56(1):A406.

40. van der Aa MP, Marieke AJE , van Mil EGAG, Knibbe CAJ, van der Vorst MMJ. Metformin: an efficacy, safety and pharmacokinetic study on the short-term and long-term use in obese children and adolescents- study protocol of a randomized controlled study, van der Aa et al. Trials. 2014; $15: 207$.

41. He M, Deng C, Huang XF. The Role of Hypothalamic H1 Receptor Antagonism in Antipsychotic-Induced Weight Gain. CNS Drugs. 2013;27:423-34.

42. Poyurovsky M, Fuchs C, Pashinian A, Levi A, Weizman R, Weizman A. Reducing antipsychoticinduced weight gain in schizophrenia: a double-blind placebo-controlled study of reboxetinebetahistine combination. Psychopharmacology. 2013;226:61522.

43. Jiamei Lian, Xu-Feng H, Pai N, Chao D. Effects of olanzapine and betahistine co-treatment on serotonin transporter, 5-HT2A and dopamine D2 receptor binding density, Progress in NeuroPsychopharmacology and Biological Psychiatry. 2013;47:62-8.

44. Barak N, Greenway FL, Fujioka K, Aronne LJ, Kushner RF. Effect of histaminergic manipulation on weight in obese adults: a randomized placebo controlled trial. International Journal of Obesity. 2008;32:1559-65.

45. Heal DJ, Gosden J, Smith SL. What is the prognosis for new centrally-actin anti-obesity drugs? Neuropharmacology. 2012;63(1):132-46.

46. Stanford J, Kaiser M, Ablah E, Dong F, PaullForney B, Early J. The effect of weight loss on fasting blood sugars and hemoglobin A1c in overweight and obese diabetics and non-diabetics. Journal of Diabetes Mellitus. 2012;2:126-30. 
47. Chowdhuy S, Carmichael KA. How valuable is measurement of C-peptide and insulin levels in type2 diabetes? Consultant. 2012;52(7):1.

48. Palmer J, Fleming G, Greenbaum C. C-peptide is the appropriate outcome measure for type 1 diabetes clinical trials to preserve B-cell function. Diabetes. 2004;59:250-64.

49. Levy JC, Matthews DR, Hermans MP. Correct homeostasis model assessment (HOMA) evaluation uses the computer program (Letter). Diabetes Care. 1998;21:2191-2.

50. Ferrannini E, Camastra S, Gastaldelli A, Maria Sironi A, Natali A, Muscelli E, et al. beta-cell function in obesity: effects of weight loss. Diabetes. 2004;53(3):S26-33.

51. Nagi DK, Yudkin JS. Effects of metformin on insulin resistance, risk factors for cardiovascular disease, and plasminogen activator inhibitor in NIDDM subjects. A study of two ethnic groups. Diabetes Care. 1993;16(4):621-9.

52. Villareal DT, Shah K, Banks MR, Sinacore DR, Klein S. Effect of weight loss and exercise therapy on bone metabolism and mass in obese older adults: a one-year randomized controlled trial. J Clin Endocrinol Metab. 2008;93(6):2181-7.

53. Fulop AK, Foldes A, Buzas E, Hegyi K, Miklos IH, Romics L, et al. Hyperleptinemia, visceral adiposity, and decreased glucose tolerance in mice with a targeted disruption of the histidine decarboxylase gene. Endocrinology. 2003;144:4306-14.
54. Barrett-O'Keefe Z, Kaplon RE, Halliwill JR. Sustained postexercise vasodilatation and histamine receptor activation following small muscle-mass exercise in humans. Exp Physiol. 2013;98(1):268-77.

55. Wang KY, Tanimoto A, Yamada S, Guo X, Ding Y, Watanabe $\mathrm{T}$, et al. Histamine regulation in glucose and lipid metabolism via histamine receptors: model for nonalcoholic steatohepatitis in mice. Am J Pathol. 2010;177(2):713-23.

56. Ali AH, Yanoff LB, Stern EA, Akomeah A, Courville A, Kozlosky M, et al. Acute effects of betahistine hydrochloride on food intake and appetite in obese women: a randomized, placebo-controlled trial. Am J Clin Nutr. 2010;92(6):1290-7.

57. Jeck-Thole S, Wagner W. Betahistine: a retrospective synopsis of safety data.Drug Saf. 2006;29(11):104959.

58. Lezius F, Adrion C, Mansmann U, Jahn K, Michael S. High-dosage betahistine dihydrochloride between 288 and $480 \mathrm{mg} /$ day in patients with severe Menière's disease: a case series. European Archives of Oto-Rhino-Laryngology. 2011;268:1237-40.

Cite this article as: Al-Anbari $\mathrm{HH}$, Sahib AS, AlMukhtar AO. Role of betahistine in glycemic control of obese subjects: a placebo- controlled clinical trial. Int J Basic Clin Pharmacol 2017;6:167-75. 